Paideusis

\title{
Queerly Inside and Out in School...A Conversation
}

\section{Terrah Keener}

Volume 22, Number 1, 2014

Sexual and Gender Diversity in Schools

URI: https://id.erudit.org/iderudit/1071465ar

DOI: https://doi.org/10.7202/1071465ar

See table of contents

Publisher(s)

Canadian Philosophy of Education Society

ISSN

0838-4517 (print)

1916-0348 (digital)

Explore this journal

Cite this article

Keener, T. (2014). Queerly Inside and Out in School...A Conversation. Paideusis, 22(1), 48-59. https://doi.org/10.7202/1071465ar

\section{Article abstract}

"Queerly Inside and Out in School ... A Conversation" draws upon the research from See Me, Hear Me ... Queerly Visible: Conversations About Family and School with Non-Heterosexual Parents and Their Children (Keener, 2012) that explored the schooling experiences of non-heterosexual parents and their children in Nova Scotia. Leveraging visual arts and performance as both a means of data generation and data representation, the generated artifacts illustrated how dominant cultural practices and narratives surrounding school and family perpetuate heteronormative ideology, while excluding and silencing non-heterosexual parents and their children. Queer visibility became a re-occurring place of reflection and tension for parents as they re-told their stories of creating a queer family presence in their child's school. The stories represented within this paper provide a window into the experience of parents and children who on a daily basis run the risk of not being "seen" by their teachers, school administrators, and the broader school community.
This document is protected by copyright law. Use of the services of Erudit (including reproduction) is subject to its terms and conditions, which can be viewed online.

https://apropos.erudit.org/en/users/policy-on-use/ 


\title{
Queerly Inside and Out in School... A Conversation
}

\author{
TERRAH KEENER \\ Mount Saint Vincent University
}

\begin{abstract}
"Queerly Inside and Out in School... A Conversation" draws upon the research from See Me, Hear Me ... Queerly Visible: Conversations About Family and School with Non-Heterosexual Parents and Their Children (Keener, 2012) that explored the schooling experiences of non-beterosexual parents and their children in Nova Scotia. Leveraging visual arts and performance as both a means of data generation and data representation, the generated artifacts illustrated how dominant cultural practices and narratives surrounding school and family perpetuate beteronormative ideology, while excluding and silencing non-heterosexual parents and their children. Queer visibility became a re-occurring place of reflection and tension for parents as they re-told their stories of creating a queer family presence in their child's school. The stories represented within this paper provide a window into the experience of parents and children who on a daily basis run the risk of not being "seen" by their teachers, school administrators, and the broader school community.
\end{abstract}

\section{Introduction}

Experience is complex and multi-dimensional. Yet, when one is identified with a marginalized population, there is a risk that others will create a story about your experience based on their assumptions about who you are. Chimamanda Adichie (2009) describes this as the "danger of the single story" (p.4). She argues that "to create a single story, show a people as one thing, as only one thing, over and over again, and that is what they become" (Adichie, 2009, p.4). Adichie illustrates her notion of a "single story" through the retelling of her experiences as a Nigerian attending university in the United States and how she was repeatedly confronted by others "story" of Africa. Adichie frames the single story as the seeds of how we create stereotypes and she emphasizes, "the problem with stereotypes is not that they are untrue, but that they are incomplete. They make one story become the only story" (p. 5). Once that "story" has been told and adopted as a "truth," it can be very hard to unravel it, or to retell it in another way. In terms of this research, See Me, Hear Me ... Queerly Visible: Conversations About Family and School With Non-Heterosexual Parents and Their Children (Keener, 2012), I tell many stories in a variety of ways to challenge teachers, school administrators, and members of the Lesbian, Gay, Bisexual, Transgendered, Two-spirited, and Queer (LGBTTQ) community to question the stories they have created about non-heterosexual parents, their children, family, and school. Using queer theory ${ }^{1}$ as a theoretical frame, my research problematizes the normalization of school and family both within

\footnotetext{
1 Queer theory recognizes that gender and sexuality are complicated and proposes lines of inquiry that challenge traditional nomenclature (Ahmed 2006a, 2006b; Villarejo, 2005; Warner 2005, 1999a, 1999b,1993; Halperin, 2003; Pinar, 2003; Sullivan, 2003; Jagose, 1996; Butler, 1993, 1990). Hall (2003) suggests that queer theory "asks us to recognize and grapple with the implications of the multiplicity and variability of identities" (p. 176). Sara Ahmed (2006b) describes this (C) Copyright 2014. The author, Terrah Keener, assigns to Paideusis the right of first publication and educational and nonprofit institutions a non-exclusive license to use this document for personal use and in courses of instruction provided that the article is used in full and this copyright statement is reproduced. Any other usage is probibited without the express permission of the Keener.
} 
the school system and the larger community by disrupting assumptions about non-heterosexual parents and the queer families they construct. It incorporates what I have termed a multi-layered narrative and artsinfluenced methodology (derived from narrative inquiry ${ }^{2}$, arts-informed research methods ${ }^{3}$, and $\mathrm{a} / \mathrm{r} /$ tography $^{4}$ ) to interrogate issues surrounding silence and queer visibility within a school setting. Leveraging visual arts and performance as both a means of data generation and datarepresentation, this research illustrates how dominant cultural practices and narratives surrounding school and family perpetuate heteronormative ideology, while excluding and silencing non-heterosexual parents and their children.

I set out to unravel the "single story" about the schooling experiences of non-heterosexual parents and their children. Conversations that I thought would revolve around the specifics of schooling, such as curriculum and school policies, morphed into lengthy, deeply personal discussions about the structure of queer families and the challenges of finding a place within a profoundly entrenched heterocentric school culture. What I heard and observed was a desire by the parents to create—or at least lay the foundation foras positive a school experience as they could provide, or hope for, for their children.

Queer visibility became a re-occurring place of reflection and tension for parents as they re-told their stories of creating a queer family presence in their child's school. Because queer visibility in the context of this research has many manifestations, I was led to the work of Janet Finch (2007) and her discussion about the art of displaying family. Finch describes the "need" to display family as an activity that is consciously acted out. The phrases display and act out increasingly took on more meaning as my research progressed and it became progressively more important for me to be able to understand and illuminate the particulars of the stories as represented by the participants. Guided by the tenets of verbatim theatre, which has its roots in documentary theatre (Fisher, 2011; Chou \& Bleiker, 2010; Lane, 2010; Lippert, 2010; Žantovská, 2010; Hutchinson, 2009; McManus, 2009; Reinelt, 2009; Freeman, 2007), I began to arrange my data, word for word, into conversations. An assemblage of stories, and ultimately a dramatic script, Queerly Inside and Out in School ... A Conversation, began to unfold, revealing the shared experience of visibility and invisibility of non-heterosexual identities within a school context.

In this paper, I explore the concept of "queer visibility" within a school context, as constructed by the parents and the children in this project. The exploration will include data from the script, 'Queerly Inside and Out in School ... Conversations ${ }^{5}$, and what follows are snippets from this dramatic script. The dialogue and the characters are taken directly from my transcripts. At no time did I combine personalities to create composite characters, nor did I add words. Deviating a little from the strictest forms of verbatim theatre, my edits were restricted to deleting words, such as "and," "ah" and "um" to aid in conversational flow. I took care to retain individual nuances in tone and inflection from the original audio taped transcripts.

tension as a "spatial formation ... bodies are sexualized through how they inhabit space" (p. 67), and explains that how we reside in a space is more accurately described as an orientation, and "orientations are about how we begin, how we proceed" (Ahmed, 2006a, p. 545). My theoretical approach to queer theory is based on the premise that queer is a personal, and temporal journey into how we position and reposition ourselves within the dominant culture and it can be a coming to or a going away from as we wrestle with the "multiplicity and variability of identity."

${ }^{2}$ Narrative inquiry operates on the premise that experience is expressed in "lived and told stories" (Pinnegar \& Daynes, 2007, p. 5).

${ }^{3}$ Burns (2004) describes arts-informed research as a way of "being and understanding (the known) in the world, in relation to other ways of being and understanding (the unknown)" (p. 219). Arts-informed research is not just aboutmethodology but about a way of positioning oneself as a researcher and an openness to explore different ways of knowing (Cole \& Knowles, 2008; Burns, 2004; Halifax, Brown, Compton \& O'Connor, 2004; Milech \& Schilo, 2004; Neilson A., 2004; Neilson L., 2004).

${ }^{4} \mathrm{~A} / \mathrm{r} /$ tography recognizes that the art and text created through inquiry are not created in a vacuum and cannot be constricted by its discipline; it is a way of interweaving aesthetic inquiry and artistic practices with analytic text as means to "convey meaning rather than facts" (Springgay, Irwin, Wilson \& Kind, 2005, p. 903).

5 The script has been performed by and for practicing and pre-service teachers as a vehicle in which to deepen the discussion around the inclusion of non-heterosexual identities in school. 


\section{Being Queerly Visible ... The Conversation Begins}

In an attempt to establish a queer and non-assimilating space into the heterocentric culture of the school, the parents in this research from Day One actively outed their queer family structures. The initial exchanges with teachers and school administrators set the stage, so to speak, to carve out a queer presence within the school.

Anne: $\quad$ I wanted her teacher to know on the first day that we're together. It's part of that indoctrination that you feel you have to do to the school system, to the administration, to all of those people. It's like, here we are ... Erin has two mothers.

Pricilla: $\quad$ The first day of school ... we made ourselves visible. (Keener, 2012, p. 110)

Anne and Pricilla clearly articulate that there is a real need to introduce and identify one's queer family to the school community. Anne's somewhat strident use of language- "It's part of that indoctrination that you feel you have to do"-is a good example of how parents physically and emotionally attempted from the beginning to construct and inhabit a queer space within the school.

Janet: I I would say generally our experience has been positive, but in a way I think part of that is because from the very get go, we made it clear that we're not going to put up with any crap! (Keener, 2012, p. 113)

Like Anne and Pricilla, Janet leaves nothing to chance. Although Janet postulates that their school experience may have been positive, her declarative statement at the end of her sentence indicates that she believes that she was able to influence that "positive" outcome by stating her expectations in clear and plain language. As well, Janet has firmly and publicly established a queer presence in her daughter's school.

Anne: $\quad$ I've had conversations with every teacher that Erin has had. I make a point to say, not only do I identify Erin as having two moms, but I identify us as a chosen family, that we chose together, as a couple, to have Erin ... I make a very distinct political statement about saying, this is a family that we have created. (Keener, 2012, p. 110)

Anne uses phrases such as "I make a point" "I identify us as a chosen family", and this is a family that we have created" to position her expectation of how she wants her family perceived and to justify why she is publicly displaying her queer family structure. Anne specifically uses the phrase "political statement" to purposefully situate her family outside of the heterocentric view of family. It was important for her to communicate to the school community that Erin was not the product of a heterosexual union. It could be that Anne did not trust "them" to see her queer family structure, or maybe Anne wanted to ensure that assumptions were not made regarding how her family came into being.

Pricilla: $\quad$ I just want to stand up and be counted as often as I possibly can, in as many settings as I possibly can. That's my political belief about educating the masses so that people don't assume by looking at me, that I'm the stepmom, or that I have a husband at home. I don't like people assuming. (Keener, 2012, p. 111)

Pricilla is clear: she demands to be recognized as a lesbian, to do otherwise would render her invisible. Anne and Pricilla both speak freely about their "politics" and their words and actions articulate their commitment to creating queer spaces within a public arena for non-heterosexual family structures.

Anne and Pricilla employ the strategy of "coming out" as a means for queering their family. For decades, queer politics have centered on the activity of coming out, of being visible. "The movement has 
veered between deploying identities that emphasize similarities to the majority, striving to be a "model minority," and deploying identities that stress differences from the heteronormative mainstream, seeking to transgress" (Bernstein \& Reimann, 2001, p. 5). Although Anne and Pricilla's acts may not be perceived as radical acts of transgression, I would argue that neither are they acts of assimilation. The act of coming out in a public forum, such as a class meeting, opens them up to public scrutiny and possible negative retribution. Bernstein and Reimann (2001) claim that "if we are to resist heteronormativity and engage in a more democratic queer politics, a variety of family structures must be visible" (p. 11). Anne and Pricilla's decision to be queerly visible in their daughter's school is most likely extremely complex and is built upon years of living and working within a society that is founded on heteronormative practices and ideals. Because they both portray their actions as "political," I interpret these actions to be liberatory acts. Anne and Pricilla are not positioning themselves to blend in; they are actively displaying their difference and demanding acknowledgement of their difference.

Amanda: $\quad$ So we have the orientation day for primary, and Sam and I go. (Pause)

There was a questionnaire, and some of the questions were ... does your son or daughter know their address, do they know their phone number, those kind of developmental things. And then the last question-do you have any special concerns about your child starting school? So we wrote, YES!

We want to know your philosophy when topics of family come up ... how is that covered? ... Have you thought about ways in which you're going to include our family ... since Nathan has two moms?

Sam: $\quad$ Assumes the role of the teacher, signified by a prop, or an attitude. Rhetorical tone. Well, what do you mean?

Amanda: Well, when Mother's Day rolls around, and you're making cards for the moms, what's going to happen? Knowing laughter is heard from other actors.

Tone very reflexive, almost as if eyebrows are raised.

Is our son going to make one card? ... Do they have the option of making two cards? ... How do you deal with blended families? ... In what ways do you talk about what makes a family? ... You know, are there ways in which you can, you know, put visuals and share stories about what that looks like? ... Because being different, you might want to make sure that there's some reflection of us in the classroom ... In what ways do you think you're going to do that?

Sam: Still responding as teacher. Oh, of course, I'll make everyone feel welcome and, you know, you can always bring your concerns to me.

Amanda: $\quad$ Sarcastic tone. I said, No, see, I'm trying not to have concerns. (Keener, 2012, pp. 112-113)

What is most poignant about this exchange between Amanda and Sam is that the last line, "No, see, I'm trying not to have concerns," encapsulates the core motivation behind many of the parents' fervent desire to display their queer family structure. By being out, they hope to divert potential conflict or prejudice towards their children by the teachers and administrators.

Sam: They were desperate for volunteers, so we put our names up. 


Amanda:
Never got a call. Around November, I called the school and I said, are you guys still
looking for volunteers? I said, I haven't gotten a call, because at that point I was
working, but I had my Wednesday mornings free and my Thursday afternoons free.

The silence, homophobia, and exclusion that Amanda and Sam experienced were what the other parents in this research dreaded. Bernstein and Reimann (2001) assert that "[q]ueer families create multiple sites where presumably private and personal decisions regarding visibility are made" (p. 13). Finch (2007) has described the need, or the desire, of presenting a family image as a means to "convey the message this is my family and it works" (p. 70). The action by non-heterosexual parents of presenting their queer family structure to their child's teacher and/or to the school administrators is a very deliberate "display of family," thus rendering them queerly visible and by doing this they are, in effect, challenging the school to "see" them and to acknowledge them.

\section{“Hey Faggot"}

The significant usage of homophobic language in school emerged as a contested site in which parents became hyper vigilant at maintaining a public queer presence. Anti-gay, homophobic language was a universal area of concern for both parents and children. The emotions expressed by parents and children regarding the flagrant use of homophobic language ranged from deep disappointment to resignation. Although both parents and children were hurt by the overt use of homophobic language, the reactions of the parents were vastly different than the reactions of the children. In many cases, the parents confronted the language where the children had resigned themselves to its use.

Amanda: $\quad$ Nathan was being called faggot ... it was a big problem on the bus, so we came in to talk to his teacher. Her response [was] "They don't know what they're saying." I said, "Do you know that?"

It's true that they may not know all the ins and outs, but do you feel like they're saying it so that they can make him feel included or are they saying it to be mean? And if they're saying it to be mean, then I would like it addressed, because it is a direct hit on WHO I am.

Sam: I mean, regardless of whether they're trying to talk about his parents or not, it's a shitty thing to say.

Amanda: $\quad$ It just happens to hit home if you're same-sex parents. (Keener, 2012, p. 116) 
Althanases and Comar (2008) argue that "name calling, in this framework, is never "just words" but words purposefully chosen to achieve particular goals" (p. 13). Amanda and Sam attempt to confront Nathan's teacher on her assumptions, challenging her to honestly reflect on the use of homophobic language by children. Amanda and Sam illustrate how homophobic language affects and hurts them as queer parents. Nathan's teacher has clearly chosen not to recognize the hurtful and hateful meaning behind homophobic name calling. Petrovic and Rosik (2007) make the distinction between "not noticing something and turning a blind eye" (p. 207). I would argue that Nathan's teacher is choosing to "turn a blind eye." Even though her default response is "They don't know what they are saying", she is refusing to look beyond what I see as her "single story" about homophobic name-calling. She is clinging to this position even though Amanda and Sam are being bluntly honest about how this language hurts them and how it is hurting Nathan.

Christine: $\quad$ Name calling is pretty insidious ... teachers are perhaps not even aware of what's going on ... On the other hand, teachers don't know how to address it. At the high school where I teach, teachers walk by comments that are homophobic all the time.

(Keener, 2012, p. 116)

During my interview with Christine, she recounted many incidents where she challenged students at the school where she taught on their use of homophobic language. Her colleagues expected her to address these issues because she was the "lesbian" on faculty. The lack of response by the teachers in Christine's school implies to the students and to the broader school community that homophobia is acceptable.

Janet: $\quad$ Slurs are still ignored in the school yard. That really drives me crazy! Because man, if somebody uses the "N" word in the school yard, let me tell you, there would be a consequence to that, but they can say, "Oh, you're so gay", or call you "faggot," and nobody really pays attention to it. (Keener, 2012, p. 116)

Janet was extremely frustrated that the school did not treat or view homophobia with the same seriousness as racial prejudice. Pinar (2007) claims that "[i]n a profession (education) presumably dedicated to diversity and equal opportunity, queers remain the last legitimate target of straights" (p. 2). As we know, language wields extraordinary power because it has the ability to regulate and control through the discursive act of naming and categorizing people. Discursive practices that identify and name heterosexuality or queerness do so in order to determine who belongs and who does not, or who is "deviant".

Christine: $\quad$ Teachers are part of creating school culture, and if they're insensitive to the issues and feel uncomfortable to address negative comments that come up in their classroom, or in the hallways, then you know, their silence is as loud as anything else. (Keener, 2012, p. 126)

Teachers are not just a part of the school culture; they are the purveyors of school culture. When a teacher does not address homophobic slurs and lets them slip "quietly" into the background, that teacher is actively enforcing heteronormativity.

Ayla: $\quad$ People say gay in a derogatory fashion

Pujita: $\quad$ You hear faggot and dyke, and everything like that, all the time. People say, oh, he's a faggot or whatever ... not on purpose ... it's in my normal vocabulary now.

Ayla: I've gotten used to it. I mean, everywhere I've gone, people do that, and nobody does anything. (Keener, 2012, pp. 116-117)

Ayla and Pujita have clearly resigned themselves to the everyday use of homophobic language. Pujita, the daughter of a gay father, has adopted the language herself and has even rationalized that the other kids are 
not really using it in a derogatory manner. What is interesting about Pujita is that she is a very active member in the Gay-Straight Alliance at her high school and positions herself politically as a "straight ally," yet she is able to justify the use of homophobic language. Butler (2004) asks the simple question "Does anybody stand by the words they utter?" Both Ayla and Pujita have released the "utterers" of these words from any responsibility. Consequently, when homophobic slurs become commonplace, as indicated by many of the participants in this research, the existence of the parents and their children become precarious, unsafe, and potentially dangerous (Althanases \& Comar, 2008; Butler, 2004).

Ayla: $\quad$ I'm out as a lesbian in my school.

Ayla: $\quad$ Lots of people, like, shot me down ... there was a girl in my class, and we used to kind of hang out, and she told her parents that I was gay, and they went, no, she thinks she's gay.

Ayla: $\quad$ (Exasperated and in the tone of her friend) No, I'm pretty sure she's gay ... (In a patronizing parental tone) No ... she thinks she's gay. How can she know at that age? (Keener, 2012, pp. 118-119)

Ayla's expressed lesbian identity and her words are questioned and even rendered as non-credible. Butler (2004) refers to the act of "what we hear" (p. 5) as a powerful tool for discerning what we believe to be real. She challenges us to "hear beyond what we are able to hear. And it means, as well, being open to narration that decenters us from our supremacy ..." (p. 18). Ayla attempts this by writing a letter to her principal.
Ayla:
We all wrote letters to the principal. I told him that people just don't understand what it is to be gay. Maybe we should include some education about being gay ... something ... just tell them what it is, because nobody knows.
Ayla:
I didn't get a response yet. He said he'd get back to me.
Janet:
The principal acknowledged her letter because I think he had to, and he said he would speak to her $\ldots$ but he never has.
Ayla:
I'd like the school to talk about something about being gay and a teenager. Like, I mean, they all get it from me, but they have to come to me and ask me if they have any questions, and often you know, they feel stupid or they just don't want to, or they couldn't care less ... teachers just don't bring it up.
Janet:
It's disappointing, even if he doesn't want to do anything about it ... He's not listening to her. (Keener, 2012, p. 124)
Perhaps Ayla's principal is unwilling to go to that place of being off centre, or maybe he is just unwilling to hear her. Consequently, Ayla's experience, her very existence in that school is imperceptible to him. And as an extension, Ayla's parents, Janet and Sara, also fade out of sight. In turn, the principal's silence is a means of communicating that homophobia is not a legitimate claim or a real experience. This reinforces the parents' decision to actively display their family structures because the consequences of not being visible can truly render them as non-existent. And once they are relegated to the margins, all of the issues that surround their queer experience, such as the flagrant use of anti-gay language, are also swept aside. 


\title{
Queer Visibility Coming Full Circle ... What Do the Children Have to Say?
}

\author{
Erin: $\quad$ I only want to tell my best friends ... (Keener, 2012, p. 111)
}

This seemingly simple statement by Erin encapsulated a common theme among many of the children I interviewed. The parents' narratives around queer visibility became "the" story that framed their schooling experience, and there was an assumption by the parents that their desire and need for a visible queer presence within the school community was also shared by their children. My conversations with the children did not support this assumption. While the parents were actively striving for a queer visible presence in their children's school, the children were just as consciously discerningly selective about when, how, and who they disclosed their queer family structures to.

$$
\begin{aligned}
& \text { Pujita: } \quad \text { I tell everybody ... unless I don't feel like they need to know. } \\
& \text { (Keener, 2012, p. 111) }
\end{aligned}
$$

Pujita's use of the phrase "unless I don't feel they need to know" is significant because she is indicating that she employs a criteria for determining who can and cannot know. Is her criteria simply close friends, or is there some other benchmark that she uses to determine how safe it is to be "known"?

Erin: $\quad$ When I talk to people and they ask stuff, like about my parents or something, I just say parents and mom, or something. But I don't actually indicate that I have two moms. (Keener, 2012, p. 114)

Erin comes from a household where both mothers are queerly visible in their community and work life; consequently, Erin is surrounded by other queer families in her social circle. On the surface, it appears counter-intuitive that Erin would be reluctant or discerning to whom she would reveal her family structure, yet she is obviously getting a message that it might not be safe or prudent to disclose this information. Erin's reticence to identify her queer family structure can be attributed to her ability to "read" and interpret the social and political policing that surround gender and sexuality in elementary school.

Erin: A lot of the kids, when I tell them, they actually think I have a stepmother and a mother. And I say to everyone in the class, I don't have a stepmother, I don't have a stepmother ... I don't have a stepmother! (Keener, 2012, p. 111)

In this exchange, we get a glimpse of the frustration that Erin faces when she does try to explain her queer family structure. The question that needs to be asked is where is Erin's teacher? Why has it been left up to Erin, at the age of eight, to explain how family structures do not have to be "one way?" I would argue that Erin has been placed in the role as teacher because her own teacher has remained silent on the topic of nonheterosexual families and identities.

Nathan: $\quad$ I remember that one day, when I was younger, we were having Mother's Day, we were making cups, and my teacher brought up that I had lesbian parents. And she's, like, whispering. And I was like, why are you whispering? (Taking on the role of the teacher in a loud whisper) ... "Well, you have two mothers. Do you want to make two cups?” ... And I was like, just talk to me straight out.

I started making two cups, and kids kept on asking me, why do you have two cups? Why do you have two cups? And I didn't know what to do because I was so freaked out that the woman was like whispering about it, So I just automatically said, oh ... I have a stepmother. And I used that one throughout all of elementary school. (Keener, 2012, p. 113) 
Although the parents in this project worked very hard not to become invisible, Nathan's experience is a stark example of how in a very brief, possibly 30-second exchange with his teacher, his family structure was rendered invisible for the next six years. Nathan's mothers, Amanda and Sam, worked exhaustively at creating a safe space for Nathan, yet his reality was one of secrecy and shame. From grade one, Nathan felt he had to adopt an alternate story about the structure of his family. What choice was he given? His teacher set the stage by whispering "You have two mothers" which, in turn, signaled to Nathan that he should probably not be forthcoming about his "two mothers."

I highlight these scenarios because they provide a snapshot of the school environments that the children in this research have to navigate. What is most worrisome about these "pictures" is that all three schools have created an environment where the children of openly queer parents feel alienated and unheard.

\section{Concluding Thoughts on Queer Visibility}

In order to create a safe space for queer families within the school system, schools must acknowledge the heteronormative behaviours and values that marginalize and silence queer parents and their children. It has been well documented that schools operate from the vantage point of dominant groups (Temple, 2005; Kozik-Rosabal, 2000; Sears, 1999; Apple, 1996; Khayatt, 1995). In the case of broadening the definition of the family, at least in the Canadian context, our schools are being pushed to a new standard by the passage of same-sex marriage in 2005. Just as the Canadian Charter of Rights and Freedoms has affirmed that all lesbian and gay people are entitled to full rights of Canadian citizenship, which includes marriage, we need to ensure that those same rights of citizenship extend to the school and are reflected in school practice. The stories represented in this research describe classrooms, teachers, and school administrators who are uncomfortable and at times unwilling to provide safe and inclusive school communities that acknowledge non-heterosexual identity and experience.

The resistance that many of the families faced within their children's schools could be interpreted as the inability of the teachers and the school administration to let go of the single story that they held regarding family and, in turn, non-heterosexual identity. The parents and the children told stories of teachers and school administrators that were unwilling to "see" their queer lives or "hear" their stories about invisibility. The parents challenged teachers and school administrators to teach and to "see" differently. As the parents presented and maintained a queer presence, the children were just as actively maintaining a low profile in order to maneuver through the system as unscathed as possible.

Pricilla: $\quad$ It's all about visibility. (Keener, 2012, p. 110)

If only it was as easy as Pricilla claims. James Sears (1999) challenges educators to "queer" their classrooms by questioning hegemonic ideology, which includes heteronormative practices that shape and inform school curriculum, pedagogy, and relationships between teachers, students, and parents. Sears calls this looking at "schooling upside down" and asks educators to explore "taken for granted assumptions about diversity, identities, childhood, and prejudice (1999, p. 5). I would like to challenge school officials to take it one step further and adopt queer pedagogy as their over-arching school philosophy. Britzman (1995) describes queer pedagogy as:

... one that refuses normal practices and practices of normalcy, one that begins with an ethical concern for one's own reading practices, one that is interested in exploring what one cannot bear to know, one interested in the imagining of a sociality unhinged from the dominant conceptual order (p. 165).

Within queer pedagogy there is room for multiple identities in the classroom and space for critically reading and interpreting the world. In order to "queer" pedagogy, the classroom and the school community must become a place where students are able to "be" their identities, meaning that they do not hide in the margins but are visibly themselves. This has the potential to oblige educators into a position of authentic inquiry, 
meaning that the lives lived by the students and families of the school community are "authentically" incorporated into the curricula and woven into the fabric of the school community.

I set out to disrupt the notion that there is a "single story" depicting the schooling experiences of nonheterosexual parents and their children and that the actions of the participants, being queerly visible, were liberatory acts that disrupt hegemonic heteronormative thought and practice. My research and findings are guided by my conviction that educational research should open us up to deeper reflection on issues and topics that influence and shape how students and their families experience the educational system. By providing alternate platforms for the stories to be seen, heard, and experienced, I have created a unique space for which readers and viewers are able to "listen" with all of their senses attuned. This extra space allows time for the stories to be contemplated on many different levels-cognitively, intuitively, and even viscerally. Stories have the ability to connect people, and my hope is that this work will connect teachers, school administrators, and members of the queer community in a way that can positively deepen their relationship with each other. 


\section{References}

Adichie, C. (2009). The Danger of a Single Story.Retrieved on May 27, 2014from http://www.ted.com/talks/chimamanda_adichie_the_danger_of_a_single_story.html

Ahmed, S. (2006a). Orientations: Toward a queer phenomenology.GLQ, 12(4), 543-573.

Ahmed, S. (2006b). Queer phenomenology: Orientations, objects, others. Durham, NC: Duke University Press.

Althanases, S., Z., \& Comar, T., A. (2008). The performance of homophobia inearly adolescents' everyday speech.Journal of LGBT Youth, 5(2), 9-32.

Apple, M., W. (1996).Cultural politics Eeducation. New York. NY: Teachers College Press.

Bernstein, M., \& Reimann, R. (Eds.). (2001). Queer families, queer politics: Challenging culture and the state. New York, NY: Columbia University Press.

Britzman, D. (1995), Is There a Queer Pedagogy? Or Stop Reading Straight, Educational Theory, 45,(2),151165.

Burns, L. (2004). Lingering, linking and layering. In A. Cole, L. Neilson, G. Knowles \& T. Luciani (Eds.), Provoked by art: Theorizing arts-informed research (pp. 214-220). Halifax, NS: Backalong Books.

Butler, J. (1990). Gender trouble. New York: Routledge Classics.

Butler, J. (1993). Bodies that matter: On the discursive limits of "sex". New York, NY: Routledge.

Butler, J. (2004). Precarious life: The powers of mourning andviolence. London, UK: Verso.

Chou, M., \& Bleiker, R. (2010). Dramatizing war: George Packer and the democratic potential of verbatim theatre.New Political Science, 32(4), 561-574.

Cole, A., L., \& Knowles, J., Gary. (2008). Arts-informed research. In J. Knowles Gary, \& A. Cole L. (Eds.), Handbook of the arts in qualitative research (pp. 55-70). Thousand Oaks,CA: Sage Publications

Finch, J. (2007). Displaying families.Sociology, 41(1), 65-81.

Fisher, A., Stuart. (2011). Trauma, authenticity and the limits of verbatim.Journal of the Performing Arts, 16(1), 112-122.

Freeman, R. (2007). Solving the Laramie problem, or, projecting onto Laramie.Theatre Symposium, 15, 107-122.

Halifax, N. D., B. Brown, V. Compton, \&M. A. O'Connor,. (2004). Imagination, walking-In/forming theory. In A. L. Cole, L. Neilsen, J. G. Knowles, \& T. C. Luciani(Eds.), Provoked by art: Theorizing artsinformed research (pp. 175-187). Halifax, NS: Backalong Books.

Hall, D. E. (2003). Queer theories. New York, NY: Palgrave Macmillan.

Halperin, D. M. (2003). The normalization of queer theory.Journal of Homosexuality, 45(2-4), 339-343.

Hutchinson, Y. (2009). Verbatim theatre in South Africa: Living history in a person's performance. In A. Forsyth, \& C. Megsen (Eds.), Get real: Documentary theatre past and present (pp. 209-222). Basingstoke Hampshire, UK: Palgrave Macmillan.

Jagose, A. (1996). Queer theory: An introduction. New York, NY: New York University Press.

Keener, T. (2012). See me hear me ... queerly visible: Conversations about family and school with non-heterosexual parents and their children (Doctoral dissertation). University of South Australia. http:// http://ura.unisa.edu.au/R/?func=dbin-jump-full\&object_id=65311

Khayatt, D. (1995). Compulsory heterosexuality: Schools and lesbian students. In M. Campbell, \& A. Manicom (Eds.), Knowledge, experience and ruling relations: Studies in the social organization of knowledge (pp. 149-163). Toronto, ON: University of Toronto Press.

Kozik-Rosabal, G. (2000). "Well, we haven't noticed anything bad going on," said the principal: Parents speak about their gay families and schools. Education and Urban Society, 32(3), 368-389.

Lane, D. (2010). Contemporary British drama. Edinburgh, UK: Edinburgh University Press.

Lippert, L. (2010). 'Life in the memory of one who no longer lives': The Laramie Project and the politics of performance. ANQ: A Quarterly Journal of Short Articles, Notes, and Reviews, 23(2), 86-95.

McManus, D. (2009). Great souls, big wheels, and other words: Experiments with truth and representation in verbatim theatre. In K. Gounaridou (Ed.), Text and Presentation 2009 (pp. 141-153). Jefferson, NC: McFarland \& Company Publishers.

Milech, B., H., \&Schilo, A. (2004). 'Exit Jesus': Relating the exegesis and creative/production components of a research thesis.Text, 3, 1-14. 
Neilson, A. (2004). Provoked by astonishment: Seeing and understanding inquiry. In A. Cole, L. Neilson, G. Knowles\& T. Luciani (Eds.), Provoked by art: Theorizing arts-informed research (pp. 52-61). Halifax, NS: Backalong Books.

Neilson, L. (2004). Aesthetics and knowing: Ephemeral principles for a groundless theory. In A. Cole, L. Neilson, G. Knowles\& T. Luciani (Eds.), Provoked by art: Theorizing arts-informed research (pp. 44-49). Halifax, NS: Backalong Books.

Petrovic, J., E., \& Rosiek, J. (2007). From teacher knowledge to queered teacher knowledge research: Escaping the epistemic straight jacket. In N. Rodriguez \& W. Pinar (Eds.), Queering straight teachers: Discourse and identity in education (pp. 201-231). New York, NY: Peter Lang.

Pinar, W. F. (2003). Queer theory in education. Journal of Homosexuality, 45(2-4), 357-360.

Pinnegar, S., \& Daynes, G., J. (2007). Locating narrative inquiry historically: Thematics in the turn to narrative. In D. J. Clandinin (Ed.), Handbook of narrative inquiry: Mapping a methodology (pp. 3-34). Thousand Oaks, CA: Sage Publications.

Reinelt, J. (2009). The promise of documentary. In A. Forsyth, \& C. Megsen (Eds.), Get real: Documentary theatre past and present (pp. 6-23). Basingstoke, Hampshire, England: Palgrave Macmillan.

Sears, J., T. (1999). Teaching queerly: Some elementary propositions. In W. J. Letts IV, \& J. T. Sears (Eds.), Queering elementary education: Advancing the dialogue about sexualities and schooling (pp. 3-13). Lanham, MD: Rowmand \& Littlefield Publishers, Inc.

Springgay, S., Irwin, R. L., \& Kind, S. W. (2005). A/r/tography as living inquiry through art and text. Qualitative Inquiry, 11(6), 897-912.

Sullivan, N. (2003). A critical introduction to queer theory. New York, NY: New York University Press.

Temple, J. R. (2005). "People who are different from you": Heterosexism in Quebec high school textbooks. Canadian Journal of Education, 28(3), 271-294.

Villarejo, A. (2005). Tarrying with the normative: Queer theory and black history. Social Text, 84/85(3/4), 6984.

Warner, M. (Ed.). (1993). Fear of a queer planet: Queer politics and social theory. Minneapolis, MN: University of Minnesota Press.

Warner, M. (1999a).The trouble with normal: Sex, politics, and the ethics of queer life. Cambridge, MA: Harvard University Press.

Warner, M. (1999b). Normal and normaller. GLQ: A Journal of Lesbian \& Gay Studies, 5(2), 119-171.

Warner, M. (2005). Publics and counterpublics. New York, NY: Zone Books.

Žantovská, E. (2010). The limits of the representation of authenticity: Documentary drama and politics today. LitterariaPragensia, 20(39), 73-91.

\section{About the Author}

Dr. Terrah Keener is an Assistant Professor and the Program Coordinator for the Bachelor of Education program at Mount Saint Vincent University in Halifax, Nova Scotia. Her research is interdisciplinary and draws upon the fields of queer theory, curriculum studies, teacher education and narrative and arts based inquiry. The notion of visibility and conversely invisibility within a school context is a strong theme throughout her research and she plans to continue leveraging arts-based inquiry as a means to work with communities, and or populations, who struggle for visibility and "place" in our education system. Currently she is leading a multi-university inquiry that is exploring how dominant cultural practices and narratives surrounding sexual identity and gender inform the experiences of Bachelor of Education students who identify as non-heterosexual, queer and/or transgendered. Dr. Keener can be reached at Terrah.Keener@msvu.ca 